\title{
BRITISH MUSEUM NATURAL RADIOCARBON MEASUREMENTS XV
}

RICHARD BURLEIGH, JANET AMBERS, and KEITH MATTHEWS Research Laboratory, The British Museum, London WC1B 3DG, England

The following list consists of dates for archaeologic and geologic samples mostly measured over the period from January 1980 to June $1981^{1}$. The dates were obtained by liquid scintillation counting of benzene using the laboratory procedures outlined in previous lists (see, eg, BM VIII, R, 1976, v 18, p 16).

Dates are expressed in radiocarbon years relative to AD 1950 based on the Libby half-life for ${ }^{14} \mathrm{C}$ of $5570 \mathrm{yr}$, and are corrected for isotopic fractionation $\left(\delta^{13} \mathrm{C}\right.$ values are relative to $\left.\mathrm{PDB}\right)$. No corrections have been made for natural ${ }^{14} \mathrm{C}$ variations (although in some instances approximate calibrated dates taken from the tables of Clark (1975) have been given in the comments where this aids interpretation of results). The modern reference standard is NBS oxalic acid (SRM 4990). Errors quoted with dates are based on counting statistics alone and are equivalent to \pm 1 standard deviation $( \pm 1 \sigma)$.

Descriptions, comments, and references to publications are based on information supplied by the persons who submitted the samples.

\section{SAMPLE DESCRIPTIONS ARCHAEOLOGIC SAMPLES \\ A. British Isles}

Late Pleistocene / early Holocene mammalian extinctions and related samples

Bone or antler samples (collagen fractions) from larger terrestrial mammals now extinct in Britain, dated as part of investigation of latest dates of survival of these spp in British Isles ( $R, 1976, \mathrm{v} 18, \mathrm{p}$ 30-31; R, 1982, v 24, p 236-238; Clutton-Brock and Burleigh, in press).

\section{Darent gravels series, Kent, England}

Bone and antler from Darent gravels, Sevenoaks $\left(51^{\circ} 20^{\prime} \mathrm{N}, 0^{\circ} 10^{\prime} \mathrm{E}\right.$, Natl Grid Ref TQ 525550). Coll 1978 and subm by D L. Harrison, Harrison Zool Mus, Sevenoaks.

BM-1618. Darent gravels

Metapodial of Equus sp, ref HZM 15.9217.

\section{BM-1619. Darent gravels}

Metapodial of Equus sp, ref HZM 8.8535.

BM-1672. Darent gravels Metapodial of Equus sp, ref HZM 92.10007.
$980 \pm 80$ $\delta^{13} C=-22.9 \%$ o

$$
\begin{array}{r}
9770 \pm \mathbf{8 0} \\
\delta^{13} C=-23.0 \%
\end{array}
$$

$115 \pm 35$ $\delta^{13} C=-22.5 \%$

${ }^{1}$ Dates obtained over part of the same period for Bronze age samples from the British Isles formed a separate list, BM XII (R, 1981, v 23, p 14-23). 
BM-1673. Darent gravels

Metapodial of Equus sp (unreg).

BM-1674. Darent graveliz

Fragmentary antler of Rangif

\section{BM-1675. Darent gravels}

Fragmentary antler of Dama dama, ref HZM 2.9766.

General Comment (RB): although 4 of these samples are of Medievalmodern date, BM-1619 is latest direct date so far obtained for horse in British Isles until re-introduced as domestic animal in late Neolithic, ca $2000 \mathrm{bc}$; BM-1674 provides additional late date for reindeer ( $c f$ dates for remains of reindeer from Anston Stones Cave, Yorkshire, BM-439: $9850 \pm 115$; BM-440a: $9940 \pm 115$; BM-440b: $9750 \pm 110$; R, 1971, v 13, p 167). Overall age range of samples reflects depositional hist of gravels, but samples selected for dating on basis of sp id, not stratigraphy (Harrison et al, 1981).

\section{BM-1676. Tolpits Lane, Hertfordshire, England}

$5230 \pm 60$ me for R Colne at Tolpits Lane, Rickmansworth $\left(51^{\circ} 40^{\prime} \mathrm{N}, 0^{\circ} 30^{\prime} \mathrm{W}\right.$, Natl Grid Ref TQ 076942). Coll 1971 by Rickmansworth Hist Soc and subm 1980 from colln of Dept Zool, British Mus (Nat Hist). Comment (RB): asscc with part of frontal bone and left horn core (ref ARC 1975 5277) wi'h cut-marks round base resulting from skinning or removal of horn with flint tools; pollen from skull (id by $\mathrm{G}$ W Dimbleby) indicated Zone VIIa (7500-5000 bp).

\section{BM-1735. Feltwell, Norfolk, England}

$11,560 \pm 110$

Radius "nd ulna (ref X. 10075 .) of Rangifer tarandus (id by A Lister) from Feltwell Fens, near Littleport $\left(52^{\circ} 30^{\prime} \mathrm{N}, 0^{\circ} 30^{\prime} \mathrm{E}\right.$, Natl Grid Rcf TL 650900). Coll ca 1870 by J Baker and subm 1980 by A Lister, Dept Zool, Univ Cambridge, from Cambridge Zool Mus colln.

\section{BM-1794. Ballybetagh, Ireland}

$15,170 \pm 160$

Fragmentary antler of Megaceros giganteus (ref NMI 58:1976) from Ballybetagh bog, near Dublin $\left(53^{\circ} 20^{\prime} \mathrm{N}, 6^{\circ} 15^{\prime} \mathrm{W}\right)$. Coll 1976 from marl beneath peat, correlated with Aller $\phi \mathrm{d}$ and subm by A Lister from colln of Natl Mus of Ireland, Dublin. Comment (RB): paraffin wax used to conserve specimen may not have been completely removed and may account for date somewhat earlier than expected (cf BM-1840, -1904, below). 
BM-1805. Creswell Crags, Derbyshire, England $\quad \begin{gathered}\mathbf{3 8} \\ \boldsymbol{\delta}^{13} C=-19.7 \% \text { o }\end{gathered}$
Fragmentary antler of Rangifer tarandus from Cresswell Crags, Worksop (532 $20^{\prime} \mathrm{N}, 1^{\circ} 10^{\prime} \mathrm{W}$, Natl Grid Ref SK 570700). Subm by J E Scott, Dept Medical Biochem, Univ Manchester Medical School, from Manchester Mus colln. Comment (RB): dated as part of investigation of survival of biopolymers in fossil material (Scott and Hughes, 1981).

\section{BM-1827. Lough Gur, Ireland}

$4020 \pm 90$

Mandibular ramus of Sus scrofa from Lough Gur, Grange, Co Limerick $\left(52^{\circ} 30^{\prime} \mathrm{N}, 8^{\circ} 30^{\prime} \mathrm{W}\right)$. Coll ca 1864 and subm 1980 from British Mus (Nat Hist) colln (ref Palaeo 38096). Comment (RB): dated in attempt to establish early occurrence of wild boar in Ireland, but date is too late to be relevant to this problem.

\section{BM-1840. RCSE 1597}

$10,920 \pm 250$

$\delta^{13} \mathrm{C}=-21.7 \%$

Rib of Megaceros giganteus (ref RCSE 1597) from Ireland (exact provenance unknown) from specimens originally in colln of Royal Coll Surgeons of England, now in British Mus (Nat Hist). Comment (RB): result agrees with expected date; cf BM-1794, above, BM-1904, below.

\section{BM-1841. Seamer Carr, N Yorkshire, England}

$8620 \pm 80$

$\mathrm{Rib}$ of Bos primigenius from complete skeleton from Seamer Carr, Seamer, $4.8 \mathrm{~km} \mathrm{~W}$ of Scarborough, Vale of Pickering, N Yorkshire $\left(54^{\circ} 15^{\prime}\right.$ N, $0^{\circ} 30^{\prime} \mathrm{W}$, Natl Grid Ref TA 030835). Coll 1980 and subm by R T Schadla-Hall for N Yorkshire Co Council, to compare with date for Star Carr (Q-14: $9557 \pm 210, \mathrm{R}, 1959$, v 1, p 69).

\section{BM-1904. Megaceros}

$11.380 \pm 280$ $\delta^{13} \mathrm{C}=-18.7 \%$

Fragments of antler of Megaceros giganteus from colln of Ulster Mus, Belfast, N Ireland. Subm by Margaret Jope, Dept Geol, Queen's Univ, Belfast, to provide direct date for specimen used in study of structure of collagen in fossil material. Comment (RB): cf BM-1794, -1840 above.

\section{Thatcham series, Berkshire, England}

Samples from gravel exposures at Thatcham, near Newbury $\left(51^{\circ} 20^{\prime}\right.$ N, $1^{\circ} 20^{\prime}$ W, Natl Grid Ref SU 503664). Part of interdisciplinary study by Kennet Valley Res Committee on depositional processes and paleoecol of region (Cheetham, 1975; Bryant and Holyoak, 1980; Holyoak, 1980). All samples except BM-1358, -1388 coll 1977 and subm by D Holyoak, Dept Geog, Univ Reading and Kennet Valley Res Committee.

BM-1358. Thatcham

$$
9280 \pm 90
$$

Wood, PW/1, from in situ tree stump at base of valley peat directly on gravels at Thatcham reed beds. Measured to check date of earliest 
Mesolithic site (Wymer, 1962; Churchill, 1962). Coll 1972 and subm by P Worsley, Dept Geog, Univ Reading and Kennet Valley Res Committee.

BM-1388. Thatcham

$11,930 \pm 80$

$\delta^{13} C=-8.7 \%$ o

Calcium carbonate from central zone of compact oblate tufa nodule, mean diam ca $25 \mathrm{~cm}$, from extensive tufa deposit, ca $2 \mathrm{~m}$ thick, overlying valley peat and gravel at Thatcham reed beds. Coll 1977 and subm by Richard Burleigh to obtain estimate of apparent age of tufa. Comment $(\mathrm{RB}): \delta^{13} \mathrm{C}$ value suggests no major dissolution or precipitation occurred after initial deposition; subtracting $5570 \mathrm{yr}$ for $50 \%$ contribution by dead carbon gives crude age of ca $6400 \mathrm{yr}$ for tufa.

\section{BM-1402. Thatcham}

$9910 \pm 80$

Wood, G9 $\alpha$ DTH (mainly Salix spp, id by D Holyoak) from lens of silty sand in cross-bedded valley bottom gravels at Thatcham reed beds Site $9 \alpha$. Measured to date assoc molluscan and macroscopic plant fossils (Kerney, 1977). Comment (DH): date places silt lens at beginning of Flandrian. Plant macrofossils and snail shells suggest cold open climate. Surprisingly late date agrees with biol and stratigraphic evidence suggesting flood plain retained open vegetation after higher ground had many trees (Holyoak, 1978).

\section{BM-1459. Thatcham}

$$
9100 \pm 70
$$

Humified wood, DTH- $\alpha 5-40 \mathrm{~cm}$, from narrow band of tufa in peat from Lower Way Gravel Pits, assoc with plant macrofossils and mollusca. Comment (DH): study of long series of exposures establishes that tufa seam results from over-bank deposition from channel in fen. Tufa was deposited early in pollen zone $\mathrm{V}$, molluscan zone b (Kerney, 1977).

$$
\begin{aligned}
& +900 \\
& 10,650 \\
& \delta^{13} C=-25.0 \%
\end{aligned}
$$

Wood, DTH- $\alpha 5-16 \mathrm{~cm}$, from beneath gravel at Lower Way Gravel Pits, assoc with pollen, plant macrofossils, and mollusca. Fractionation correction estimated. Measured to compare assoc material with that from Thatcham Mesolithic site. Comment (DH): pollen zone IV, molluscan zone $\mathrm{z}$ or perhaps early a.

BM-1634. Thatcham

$$
\begin{array}{r}
\mathbf{8 1 6 0} \pm \mathbf{5 6 0} \\
\delta^{13} C=-27.1 \% \text { \% }
\end{array}
$$

Charcoal, DTH Th $\alpha 6 \mathrm{~h}$, from autochthonous tufa in palaeochannel, 50 to $60 \mathrm{~cm}$ above river gravels at Thatcham reed beds. Comment (DH): samples from same level as pollen spectrum transitional between zones $\mathrm{V}$ and VIa. 


\section{BM-1635. Thatcham} Wood, DTH Th $\alpha 6 \mathrm{~d}$, from autochthonous mud/tufa in palaeochannel, $20 \mathrm{~cm}$ above river gravels at Thatcham reed beds, $40 \mathrm{~cm}$ lower than BM-1634, above. Comment $(\mathrm{DH})$ : pollen and molluscan spectrum very similar to that surrounding DTH Th $\alpha 6 \mathrm{~h}, \mathrm{BM}-1623$, above.

\section{BM-1636. Thatcham}

$\mathbf{9 3 8 0} \pm \mathbf{8 0}$

Wood, DTH Th $\mathrm{Bj}$ (Betula, id by D Holyoak) from top $10 \mathrm{~cm}$ fluvial gravels underlying fen (DH): pollen from this level zone IV; molluscan zone $\mathrm{z}$.

\section{BM-1637. Thatcham}

$9170 \pm 140$

Wood, DTH Th $\alpha 80$ (Pinus, id by D Holyoak) from humified fen peat ca $1 m$ thick at Thatcham reed beds and measured to date early Boreal pollen and plant microfossil spectra. Comment (DH): pollen from this level zone V; molluscan zone $\mathrm{b}$.

General Comment (DH): cf BM-1135: $8929 \pm 71$ and BM-1136: $9228 \pm$ $100 ; \mathrm{R}, 1979$, v 21, p 345 also for Thatcham, and dates for Brimpton BM-1638, -1874 below.

\section{Brimpton series, Berkshire, England}

Samples from gravel pit NE of Brimpton $\left(51^{\circ} 20^{\prime} \mathrm{N}, 1^{\circ} 10^{\prime} \mathrm{W}\right.$, Natl Grid Ref SH 567652). Part of investigation of Kennet Valley terraces (Cheetham, 1975; Bryant and Holyoak, 1980; Holyoak, 1980). Coll 1979 (BM-1638) and 1980 (BM-1874) and subm by D Holyoak.

\section{BM-1638. Brimpton}

$$
\begin{array}{r}
27,400 \pm 1250 \\
\delta^{13} C=-24.4 \% 0
\end{array}
$$

Sample DTH Br 64, plant debris comprising stems, leaves, and seeds of variety of herbs and small shrubs (id by D Holyoak), sieved from clay and silt lens in fluvial gravels. Comment (DH): pollen shows open herbaceous vegetation in region. Plant macrofossils and mollusca suggest open conditions with cold climate. Date is surprisingly early.

\section{BM-1874. Brimpton}

$29,500 \pm 460$

Small twigs (Salix spp, id by D Holyoak) from silty clay forming channel fill at top of London Clay, beneath $2 \mathrm{~m}$ of bedded river gravels. Comment (DH): assoc pollen, plant macrofossils, Coleoptera and Mollusca, show open vegetation in region with cold climate. Confirms BM1638, above.

General Comment (DH): cf dates for Thatcham BM-1135, -1136, R, 1979, v 21, p 345 and BM-1358, -1388, -1402, -1459, -1460, -1634 to -1637, above. 


\section{Milfield North series, Northumberland, England}

Charcoal from Pit 2, one of terminal pits in double pit row, in pit alignment near henge monument at Milfield North (Harding, 1981), Wooler $\left(55^{\circ} 35^{\prime} \mathrm{N}, 2^{\circ} 10^{\prime} \mathrm{W}\right.$, Natl Grid Ref NT 934351), assoc with Grooved Ware pottery. Coll 1978 and subm by A F Harding, Dept Archaeol, Univ Durham.

BM-1650. Milfield North

Sample 1978/128 from Layer 11.

\section{BM-1652. Milfield North}

Sample 1978/125 from Layer 12.

\section{BM-1653. Milfield North}

Sample 1978/124 from Layer 13. Ware, probably because of redeposition. Contemporaneity with dates for henge (BM-1149: $3774 \pm 39$, -1150: $3801 \pm 62$; R, 1979, v 21, p 346) presumably indicates pits are part of same building activity and may be connected with henge in function.

$$
\begin{array}{r}
\mathbf{3 7 4 0} \pm \mathbf{5 0} \\
\delta^{13} C=-25.7 \% \text { o }
\end{array}
$$

$$
\begin{array}{r}
\mathbf{3 7 7 0} \pm \mathbf{5 0} \\
\delta^{13} C=-25.4 \% \text { o }
\end{array}
$$

$$
3610 \pm 80
$$$$
\delta^{13} C=-23.8 \%
$$

\section{BM-1678. Southwark, London}

$1740 \pm 35$

Cellulose from wood (Alnus glutinosa, id by A Slack) from timber raft at sub-base of Roman Watling St, Southwark, London $\left(51^{\circ} 30^{\prime} \mathrm{N}\right.$, $0^{\circ} 10^{\prime}$ W, Natl Grid Ref TQ 326797). Coll 1979 and subm by M Dean, Southwark and Lambeth Archaeol Excavation Committee.

\section{Lingey Fen series, Cambridgeshire, England}

Collagen from animal bone and antler from Lingey Fen, Grantchester, near Cambridge $\left(52^{\circ} 10^{\prime} \mathrm{N}, 0^{\circ} 10^{\prime} \mathrm{E}\right.$, Natl Grid Ref TL 450585), found during construction of Cambridge W Bypass, at crossing of R Cam. Full stratigraphic control of samples not possible as colln made during brief intervals when construction work suspended, but bones fall into two groups from "upper" and "lower" peat, both with similar faunal assemblages, many slightly abraded by river transport. Coll 1980 by M Miller, T Miller, and J Pullinger, and subm by A J Legge, Dept Extra Mural Studies, Univ London.

BM-1707. Lingey Fen

$$
\begin{array}{r}
\mathbf{4 6 3 0} \pm \mathbf{5 0} \\
\delta^{1 s} C=-22.0 \%
\end{array}
$$

Left mandible of Bos primigenius. Fractionation correction estimated.

\section{BM-1708. Lingey Fen}

$$
\begin{array}{r}
\mathbf{6 3 7 0} \pm \mathbf{7 0} \\
\boldsymbol{\delta}^{1 s} \mathrm{C}=-22.0 \%
\end{array}
$$

Proximal metatarsal of Bos primigenius. Fractionation correction estimated. 
BM-1709. Lingey Fen

Horse tibia from upper peat.

BM-1711A. Lingey Fen

Collagen from red deer ante peat, obtained by standard extraction method, (dilute $\mathrm{HCl}$ ).

\section{BM-1711B. Lingey Fen}

Collagen from part of same antler used for BM-1711A, above, extracted using method developed by Longin (1970).

General Comment (AJL): BM-1711A, -1711B date earliest phase of peat accumulation (cf BM-1709 from upper peat). Remains of Bos primigenius (BM-1707, -1708) apparently redeposited from earlier sediments. Detailed rept on assemblage will be pub (Legge, ms in preparation).

\section{Molluscan zonation samples}

Charcoal assoc with terrestrial Mollusca (land snails) dated to provide time scale for molluscan and plant biostratigraphy and comparison with dates for shells of selected spp of land snails from same horizons (Burleigh and Kerney, 1982; Kerney, Preece, and Turner, 1980; dates for snails to follow).

\section{BM-1736. Caerwys, Clwyd, Wales}

$7880 \pm 160$

Charcoal from 390 to $393 \mathrm{~cm}$ (base of buried soil) in profile through tufa deposit $\left(53^{\circ} 15^{\prime} \mathrm{N}, 3^{\circ} 20^{\prime} \mathrm{W}\right.$, Natl Grid Ref SJ 105730). Coll 1980 and subm by R C Preece, Dept Geol, Imperial Coll, London. Comment (RCP): dates base of molluscan zone c (sensu Kerney, Preece, and Turner, 1980), although sequence very condensed at this level.

\section{BM-1737. Binel Point}

$4480 \pm 100$

$\delta^{1 s} C=-27.2 \%$

Charcoal from buried soil (lower soil) within landslip complex at Binel Pt, near St Lawrence, Isle of Wight, England $\left(50^{\circ} 35^{\prime} \mathrm{N}, 1^{\circ} 15^{\prime} \mathrm{W}\right.$, Natl Grid Ref SZ 545765). Coll 1980 and subm by R C Preece. Comment (RCP): molluscan assemblage from this soil is assignable to zone d (sensu Kerney, Preece, and Turner, 1980); date also provides chronol for hist of landslipping in area.

\section{BM-1738. Millpark, Co Offaly, Ireland}

$3190 \pm 170$

$\delta^{13} C=-26.1 \%$ o

Charcoal from 120 to $140 \mathrm{~cm}$ in soil horizon within tufa deposit at Millpark, near Roscrea ( $\left.53^{\circ} 0^{\prime} \mathrm{N}, 7^{\circ} 50^{\prime} \mathrm{W}\right)$. Coll 1980 and subm by R C Preece. Comment (RCP): molluscan assemblage for this level contains many woodland snails ( $c f$ zone d). Fuller discussion given in Preece and Robinson (in press). 
BM-1795. Castlethorpe, Lincolnshire, England

$\mathbf{3 4 1 0} \pm \mathbf{8 0}$

$\delta^{13} \mathrm{C}=-26.5 \%$ o

Charcoal (mainly Quercus sp, id by J F Levy) from clearance horizon in upper levels $\left(60\right.$ to $85 \mathrm{~cm}$ ) of tufaceous deposit near Castlethorpe $\left(53^{\circ}\right.$ $30^{\prime} \mathrm{N}, 0^{\circ} 30^{\prime} \mathrm{W}$, Natl Grid Ref SE 988075). Coll 1980 and subm by R C Preece. Comment (RCP): dates temporary forest clearance horizon (zone e).

\section{BM-1837. Rodney Stoke, Somerset, England}

$7940 \pm 180$

$\delta^{13} C=-24.9 \%$

Charcoal from 163 to $153 \mathrm{~cm}$, in tufa, Pit 2 at Manor Farm, Rodney Stoke, near Cheddar $\left(51^{\circ} 15^{\prime} \mathrm{N}, 2^{\circ} 45^{\prime} \mathrm{W}\right.$, Natl Grid Ref ST 480499). Coll and subm by M J Willing, Dept Geog, Univ Sussex. Comment (RCP): dates base of zone d.

\section{Freshwater shell series}

Shell carbonate (id as aragonite by x-ray diffraction) from Margaritifera auricularia (Spengler), id by R C Preece, large pearl mussel now extinct in Britain (Jackson and Kennard, 1909; Kennard, 1943; Kennard, Salisbury, and Woodward, 1925), from bed of $\mathrm{R}$ Thames in $\mathrm{W}$ London, England $\left(51^{\circ} 30^{\prime} \mathrm{N}, 0^{\circ} 15^{\prime} \mathrm{W}\right.$, Natl Grid Ref TQ 220780). Coll 19801981 by E A Jarzembowski, Dept Entomol, British Mus (Nat Hist) (BM1800 from $\mathrm{BM}(\mathrm{NH})$ colln, 1910) and subm by $\mathrm{M}$ P Kerney and $\mathrm{R} \mathrm{C}$ Preece, Dept Geol, Imperial Coll, London. Shells were well-preserved, but only innermost layers were used for dating; outer layers were removed by sandblasting followed by leaching with dilute acid.

\section{BM-1798. Freshwater shell carbonate}

From bed of $\mathrm{R}$ Thames at Hammersmith.

BM-1799. Freshwater shell carbonate

From bed of R Thames at Putney.

\section{BM-1800. Freshwater shell carbonate}

From bed of $\mathrm{R}$ Thames at Mortlake.

$$
\begin{array}{r}
4860 \pm 40 \\
\delta^{13} C=-10.1 \%
\end{array}
$$

$$
\begin{array}{r}
\mathbf{4 3 4 0} \pm \mathbf{4 5} \\
\delta^{13} C=-10.5 \%
\end{array}
$$

$$
\begin{array}{r}
\mathbf{4 1 4 0} \pm \mathbf{5 0} \\
\delta^{13} C=-9.6 \%
\end{array}
$$

General Comment (RB): shells of $M$ auricularia have been dredged from $\mathrm{R}$ Thames in supposed assoc with Neolithic polished stone artifacts (Kennard, 1923), although Ipswichian (last interglacial) occurrence of sp in Britain is also recorded (Kerney, 1958). Modern specimens coll live from European rivers at known dates are being sought for estimate of apparent age of shell carbonate in this sp, but uncorrected result confirms Holocene age for shells from present bed of $\mathrm{R}$ Thames. More detailed discussion will be pub elsewhere (Preece $e t a l$, in press).

\section{Bone samples from caves}

Samples dated as part of investigation of rate of movement of bone within cave systems (formation of archaeol deposits in fissures). 
BM-1808. Swildon's Hole, Somerset, England

$$
1730 \pm 60
$$

Collagen from femur of domestic ox (id by Juliet Clutton-Brock, Dept Zool, British Mus (Nat Hist)) from Swildon's Hole, Priddy, Mendip $\left(51^{\circ} 15^{\prime} \mathrm{N}, 2^{\circ} 40^{\prime} \mathrm{W}\right.$, Natl Grid Ref ST 531513), from beyond Sump no. 4 at depth ca $130 \mathrm{~m}$. Coll 1979 and subm by P J Andrews, Dept Palaeontol, British Mus (Nat Hist).

\section{Foel Fawr series, Dyfed, Wales}

Collagen from samples of bone and horn core of Bos primigenius (id by Juliet Clutton-Brock) from floor of bone chamber, Foel Fawr cave, Llandovery $\left(52^{\circ} 0^{\prime} \mathrm{N}, 3^{\circ} 50^{\prime} \mathrm{W}\right.$, Natl Grid Ref SN 734188). Coll 1979 by R R Murphy, Leicestershire Speleol Assoc and subm by P J Andrews.

\section{BM-1809. Foel Fawr}

$5240 \pm 80$

Fragmentary tibia of Bos primigenius (ref Sample 2).
BM-1810. Foel Fawr
Fragment of horn core of Bos primigenius (ref Sample 1).
$5210 \pm 130$
$\delta^{13} \mathrm{C}=-22.8 \%$

\section{BM-1903. Foel Fawr}

$5100 \pm 360$

Fragmentary long bone of ungulate, probably Bos primigenius (ref Sample 3).

General Comment (PJA): sample from Swildon's Hole came from deep within cave and almost certainly reached this position through aven immediately above, which reaches to within $5 \mathrm{~m}$ of ground surface; three samples from Foel Fawr cave also entered through similar aven. Significance of these bone accumulations in caves, and their ages and rates of accumulation will be subject of forthcoming paper (Burleigh and Andrews, ms in preparation).

\section{Peninsular House series, London}

Charcoal from wine barrels destroyed in Great Fire of London (AD 1666), from buried cellar, Peninsular House $\left(51^{\circ} 30^{\prime} \mathrm{N}, 0^{\circ} 10^{\prime} \mathrm{W}\right.$, Natl Grid Ref TQ 330810). Coll 1979 and subm by G Milne, Dept Urban Archaeol, Mus London.

\section{BM-1824. Peninsular House}

$$
\delta^{13} C=-25.6 \%
$$

Barrel staves (Quercus sp). Comment (RB): calibrated date, AD 1685 \pm 70 (Clark, 1975).

\section{BM-1825. Peninsular House}

Barrel hoops (Castanea sativa). Comment (RB): calibrated date, AD $1640 \pm 70$ (Clark, 1975). 
Down Farm series, Dorset, England

Charcoal from Bronze-age settlement site at Down Farm, Blandford Forum $\left(50^{\circ} 50^{\prime} \mathrm{N}, 2^{\circ} 10^{\prime} \mathrm{W}\right.$, Natl Grid Ref ST 880075) assoc with sequence of Deverel-Rimbury pottery, enclosure, and roundhouse. Coll 1979-1980 and subm by R Bradley, Dept Archaeol, Univ Reading. Comment supplied by R Bradley.

\section{BM-1850. Down Farm}

From Ditch 1.

\section{BM-1851. Down Farm}

From burned layer between Layers 5 and 6 .

\section{BM-1852. Down Farm}

From burned flint dump.

\section{BM-1853. Down Farm}

From burned flint dump.

\section{BM-1854. Down Farm}

From burned flint dump.

$$
2680 \pm 130
$$$$
\delta^{13} C=-26.8 \%
$$

$$
\begin{array}{r}
\mathbf{2 7 3 0} \pm \mathbf{5 0} \\
\delta^{13} C=-25.5 \% \text { o }
\end{array}
$$

$$
2740 \pm 40
$$$$
\delta^{13} C=-25.6 \%
$$

$$
\mathbf{2 7 9 0} \pm \mathbf{4 5}
$$$$
\delta^{13} C=-25.6 \%
$$

$$
2800 \pm 45
$$$$
\delta^{13} \mathrm{C}=-25.3 \%
$$

General Comment (RB): results form completely consistent series apparently spanning main period of use of site and agree with results from nearby sites of Handley Barrow 24 (BM-1644 to -1649; R, 1981, v 23, p 20-21), and South Lodge Camp (BM-1917 to -1922; BM XVI, in press). For other dates from Bronze age sites in Britain, see BM XII, R, 1981, v 23, p 14-23.

\section{Vazon series, Guernsey, Channel Islands}

Wood (Alnus) from Vazon $\left(49^{\circ} 20^{\prime} \mathrm{N}, 1^{\circ} 20^{\prime} \mathrm{W}\right.$, Natl Grid Ref WV 284796). Coll 1980 by D Keen and subm by I A Kinnes, Dept Prehist and Romano-British Antiquities, British Mus.

\section{BM-1858. Vazon}

$$
3190 \pm 210
$$

From $5 \mathrm{~cm}$ below surface of foreshore peat. Comment (IAK): date is too young by comparison with BM-1859, below, SRR-437 (3989 \pm 50 , R, 1979 , v 21, p 224), and pollen evidence from peat; cf many young dates from foreshore peats in Finisterre (Morzadec-Kerfourn, 1974).

\section{BM-1859. Vazon}

$$
4000 \pm 50
$$

From center of $20 \mathrm{~cm}$ rooted stump on surface of foreshore peat. Comment (IAK): outline pollen analysis confirms late middle Flandrian age. Date compares closely with SRR-437 (cited above) from foreshore peat at St Ouen's Bay, Jersey, also from rooted Alnus and Corylus. Pollen from this locality also suggests late middle Flandrian age (Keen, 1981). 


\section{Les Fouaillages series, Guernsey, Channel Islands}

Charcoal from Neolithic mound of Les Fouaillages (Kinnes, 1982; Keen, 1981), Vale Parish $\left(49^{\circ} 30^{\prime} \mathrm{N}, 2^{\circ} 30^{\prime} \mathrm{W}\right.$, Natl Grid Ref WV 5830). Coll 1980-1981 and subm by I A Kinnes.

BM-1891. Les Fouaillages

$$
3850 \pm 50
$$

Sample 14/12 174, from mortuary complex.

\section{BM-1892. Les Fouaillages}

Sample 17/10 55954 , from primary mound assoc with decorated pot.

$\mathbf{5 5 1 0} \pm \mathbf{6 0}$

BM-1893. Les Fouaillages

$\delta^{13} C=-25.5 \%$ o

Sample 17/12 F59 354, from same context as BM-1892, above.

$\begin{array}{lr}\text { BM-1894. Les Fouaillages } & \mathbf{5 2 8 0} \pm \mathbf{1 4 0} \\ \text { Sample 16/09 F52 334, from floor of primary stone chamber. } & \delta^{1 s} C=-24.8 \% \text { o }\end{array}$

Sample 16/09 F52 334, from floor of primary stone chamber.

\section{BM-1895. Les Fouaillages}

Sample 01/97 F56 359, from hearth.

\section{BM-1896. Les Fouaillages}

Sample 04/99 F55 358, from hearth.

\section{BM-1897. Les Fouaillages}

Sample 05/96 F68 397, from posthole.

$$
\begin{array}{r}
4000 \pm \mathbf{6 0} \\
\delta^{13} C=-25.6 \% \text { o } \\
\mathbf{5 0 9 0} \pm \mathbf{5 0} \\
\delta^{13} C=-25.6 \% 0 \\
\mathbf{3 8 2 0} \pm \mathbf{5 0} \\
\delta^{13} C=-25.3 \% \text { o }
\end{array}
$$

General Comment (IAK): BM-1892, -1893 date construction of unique triangular mound with mortuary structures assoc with final Bandkeramik material of Fouaillages/Pinnacle style, and agree with expected chronol. BM-1894 provides broad dating for backfill of primary central chamber. BM-1891, -1895, -1897 are assoc with closure of later mortuary structure and final mound, with adjacent domestic site, and are consistent with rich Beaker-period assemblage; BM-1896 is clearly anomalous in this context.

\section{Canadian Arctic series}

\section{B. Canada}

Collagen from samples of mammalian bone, antler, and horn from Bathurst and Ellesmere Is, Canadian High Arctic, Northwest Territories, Canada (ca $79^{\circ} \mathrm{N}, 75^{\circ} \mathrm{W}$ ). Coll 1979 by A J Sutcliffe, D Gill, R McGhee, and P Schledermann (courtesy Polar Continental Shelf Proj) and subm by A J Sutcliffe, Dept Palaeontol, British Mus (Nat Hist), to help establish length of survival and processes of decay of bone and soft tissue on land surfaces underlain by deep permafrost and under prolonged seasonal snow cover, and to compare dates of remains of terrestrial and marine mammals (see, eg, McGhee and Tuck, 1976). 
BM-1751. Canadian Arctic

Walrus bone ref BPMPS 1 , from surface at Bache Peninsula Old Mounted Police Sta, Ellesmere I. Surface find assumed contemporary with occupation of MP Sta, ca 1926-1952.

\section{BM-1753. Canadian Arctic}

$360 \pm 25$ $\delta^{1 s} \mathrm{C}=-21.7 \%$

Walrus vertebra, ref ERS 1b, from Eskimobyen, Knud Peninsula, Ellesmere I. One of group of assoc vertebrae including intervertebral disc, lying on ground surface and believed assoc with nearby Thule occupation site.

\section{BM-1754. Canadian Arctic}

Walrus bone, ref Sq-Fm-3/1, from ground surface beside Dorset long house, Knud Peninsula, Ellesmere I.

BM-1766. Canadian Arctic

$155 \pm 40$

$\delta^{13} C=-23.9 \%$

Horn from skull of musk ox, ref 9, from surface, near High Arctic Research Sta, Bathurst I.

BM-1767. Canadian Arctic

$$
85 \pm 40
$$

Horn core of musk ox skull, ref 9 , dated by BM-1766, above.

\section{BM-1803. Canadian Arctic}

$$
\mathbf{8 7 0} \pm 30
$$

Caribou antler from permanently frozen floor of Thule House 3, Brooman Pt, Bathurst I. Part of assoc series of marine and terrestrial mammal remains impregnated with seal oil and frozen since deposition; removal of seal oil from collagen difficult, but apparently complete. Fractionation correction estimated.

BM-1804. Canadian Arctic

$$
\mathbf{8 0 0} \pm \mathbf{3 0}
$$

$$
\delta^{13} \mathrm{C}=-22.0 \%
$$

Caribou antler from same context as BM-1803, above. Fractionation correction estimated.

General Comment (AJS): BM-1754, -1803, -1804 agree with archaeol evidence (Schledermann, 1978, 1981; McGhee, 1980). BM-1751, -1753 estimate apparent age for bone of marine origin; BM-1753, -1754 indicate long survival of bone and assoc soft parts (BM-1753; intervertebral disc) in relatively unaltered state on arctic land surface; BM-1766, -1767 from same musk ox skull provide measurement of rates of differential weathering of bone and horn exposed on surface of ground. Further comparisons needed between BM-1803, -1804 (caribou antler) and assoc bones of whale, walrus, seal, polar bear, and arctic fox from same context, but these samples impregnated with seal oil found very difficult to remove by pretreatment. Taphonomic aspects will be discussed more fully elsewhere (Sutcliffe, $\mathrm{ms}$ in preparation). 


\section{Platyvola series}

$$
\text { C. Crete }
$$

Collagen from bone samples from Platyvola Cave used during Neolithic, Minoan, Post Palatial, and possibly later periods (Faure, 1969), W side of gorge above Plain of Kerameia, NE Skourachlada $\left(35^{\circ} 30^{\prime} \mathrm{N}\right.$, $\left.24^{\circ} 0^{\prime} \mathrm{E}\right)$. Coll 1980 by Tina McGeorge and subm by $\mathrm{R}$ Jones, British School at Athens, for Y Tzedakis, Archaeol Mus Chania.

BM-1813. Platyvola

Sample 10, long bones from cleft.

\section{BM-1814. Platyvola}

Sample 13, mixed animal and human bones.

BM-1815. Platyvola

Sample 14, animal bones.

BM-1816. Platyvola

Sample 32, animal and human bones.

BM-1826. Platyvola

Sample 54, human bones.

\section{Kalavasos-Ayious series}

D. Cyprus

$$
\begin{array}{r}
\mathbf{4 0 3 0} \pm \mathbf{5 0} \\
\delta^{13} C=-19.8 \% \text { o }
\end{array}
$$

$$
\begin{array}{r}
\mathbf{3 8 0 0} \pm \mathbf{5 0} \\
\delta^{13} C=-20.0 \% \text { o }
\end{array}
$$

$$
\begin{array}{r}
1040 \pm 50 \\
\delta^{13} C=-20.3 \% o
\end{array}
$$

$$
\begin{array}{r}
3800 \pm 40 \\
\delta^{13} C=-20.2 \% \text { \% }
\end{array}
$$

Charcoal from Chalcolithic site at Kalavasos-Ayious, SE of Kalavasos village, Larnaca Dist, S Cyprus $\left(34^{\circ} 40^{\prime} \mathrm{N}, 33^{\circ} 20^{\prime} \mathrm{E}\right)$. Coll 1979 and subm by I A Todd, Cyprus Am Archaeol Res Inst, Nicosia (Todd, 1979a, b; 1981; in press).

BM-1832. Kalavasos-Ayious

Sample 5 from NW area, Pit 2, 6.3.

BM-1833. Kalavasos-Ayious Sample 6 from C11C, 6.1.

BM-1834. Kalavasos-Ayious Sample 8 from NW area, F117.4.

BM-1835. Kalavasos-Ayious Sample 10 from C11B 6.1.

$$
\begin{array}{r}
4810 \pm 45 \\
\delta^{13} C=-24.6 \% \\
4780 \pm 140 \\
40 \\
\delta^{13} C=-25.5 \% 0
\end{array}
$$
$4800 \pm 70$
$\delta^{1 s} C=-25.2 \% 0$

$$
10,790 \pm 80
$$

$\delta^{13} C=-24.2 \%$ o 


\section{BM-1836. Kalavasos-Ayious}

$4480 \pm 290$

Sample 11 from C11C 6.2.

$\delta^{13} C=-25.1 \%$

General Comment (IAT): although series is not entirely consistent and BM-1835 must be discounted on archaeol grounds, dates indicate site is approx contemporary with Kissonerga Mylouthkia (BM-1473 to -1476, -1539, -1540, R, 1982, v 24, p 238-239) in Paphos region, as suggested by general appearance of site. Dates confirm impression from other sites on Cyprus of considerable gap in occupation after end of aceramic Neolithic and before onset of ceramic Neolithic/Chalcolithic occupation. Evidence from this site and Kissonerga Mylouthkia strongly suggests period characterized by pits followed by period characterized by lightly-built huts as at Lemba-Lakkous (BM-1353, -1354, -1541 to -1543, R, 1982, v 24, p 238). Groups coming from general area of Kalavasos may have been responsible for sites such as Mylouthkia (Todd, in press).

\section{Manchester mummy series}

$$
\text { E. Egypt }
$$

Bone (collagen) and linen bandage from Egyptian human mummy no. 1770, adolescent female, from colln of Manchester Mus (acquired ca 1895; exact provenance unknown, but possibly from Hawara ca $29^{\circ} \mathrm{N}$, $31^{\circ}$ E). Coll 1975 during dissection of mummy and subm 1980 by $\mathrm{A}$ Rosalie David, Manchester Mus, to help settle question of possible rewrapping of mummy (David, 1979).

\section{BM-1602. Manchester mummy 1770}

Collagen from left humerus (ref 1770/169).

\section{BM-1839. Manchester mummy 1770}

Linen bandage from immediately below cartonnage.

General Comment (RB): collagen extracted from femur was poorly preserved and may have been contaminated with older or younger material; dates do not agree with those obtained by Hodge and Newton (see David, 1979, p 137-147) of ca 770 bc for bone from mummy 1770 and ca ad 380 for bandage (no lab nos.), although same trend for bones of mummy to appear older than bandage is observed.

\section{Tell el-Dab'a series}

Charcoal from Tell el-Dab'a (Bietak, 1979), N of Faqûs, Markaz Faqûs, Sharqiya Prov $\left(30^{\circ} 50^{\prime} \mathrm{N}, 31^{\circ} 50^{\prime} \mathrm{E}\right)$. Coll 1978 and subm by $\mathrm{M}$ Bietak, Osterreischisches Archäol Inst, Cairo.

BM-1726. Tell el-Dab'a

Sample 1.

BM-1727. Tell el-Dab'a

Sample 2.

$$
\begin{array}{r}
3410 \pm 60 \\
\delta^{1 s} C=-26.4 \% o
\end{array}
$$

$$
\mathbf{3 1 8 0} \pm \mathbf{5 0}
$$

$\delta^{1 s} C=-21.0 \%$ 
BM-1728. Tell el-Dab'a

Sample 3.

\section{Deir-el-Bahri series}

Wood (Acacia sp, id by Rowena Gale, Royal Botanic Gardens, Kew) and thong taken from wooden wheel from Middle Kingdom tomb at Deir-el-Bahri, W bank of $\mathrm{R}$ Nile, Thebes $\left(25^{\circ} 40^{\prime} \mathrm{N}, 32^{\circ} 40^{\prime} \mathrm{E}\right)$ in colln of Dept Egyptian Antiquities, British Mus (Reg no. EA29943). Coll ca 1896 by E Naville and subm 1980 by W V Davies, Dept Egyptian Antiquities. Dated in connection with centennial exhibition of Egypt Exploration Soc (1982).

\section{BM-1796. Deir-el-Bahri wheel}

Wood drilled axially from outer edge of wheel.

BM-1796A. Deir-el-Bahri wheel

Repeat measurement of BM-1796 following measurement of BM-1797.

\section{BM-1797. Deir-el-Bahri wheel}

Thong used to bind cracks in wheel.

$$
\begin{array}{r}
\mathbf{3 4 9 0} \pm \mathbf{4 0} \\
\delta^{13} C=-26.3 \%
\end{array}
$$

$$
3520 \pm 60
$$

$\delta^{13} \mathrm{C}=-26.3 \%$ o

General Comment (RB): BM-1796, -1796A provide max age for wheel and may indicate date of manufacture as early as Middle Kingdom (mid12th Dynasty, ca $1910 \mathrm{BC}$ ), but date for thong (BM-1797), for which no age allowance needed, suggests most likely period of use within Second Intermediate Period, ca $1660 \mathrm{BC}$; full discussion will be pub elsewhere (Davies and Burleigh, $\mathrm{ms}$ in preparation).

\section{Gawāsīs series}

Samples from shrine at mouth of Wādī Gawāsīs, N of Quseir, on Red Sea coast $\left(26^{\circ} 40^{\prime} \mathrm{N}, 34^{\circ} 10^{\prime} \mathrm{E}\right)$ assoc with Pharaonic port (Sayed, 1977; 1978; 1980). Coll 1976 and subm by A M Sayed, King Abdulaziz Univ, Jiddah.

BM-1844. Gawāsīs

$$
3230 \pm 45
$$

$\delta^{13} C=-23.3 \%$ o

Knot of rope (Desmostachya sp, id by D Cutler, Royal Botanic Gardens, Kew), from beside shrine of Ankhow and assoc with texts of Sesostris I. Comment (AMS): date is surprisingly late, as Sesostris I began reign ca $1970 \mathrm{BC}$ and there is no inscriptional evidence later than lst half of 12th Dynasty, ca 19th century BC.

BM-1845. Gawāsīs

$3555 \pm 40$

Wood (Cedrus sp, id by D Cutler). Comment (AMS): cedar is not native to region. Date is in line with hieroglyphic texts of Sesostris I. 


\section{BM-1872. Bristol mummy no. $\mathbf{H 7 3 8 6}$}

$2880 \pm 140$

Wood from sarcophagus (ref $\mathrm{H} 64 \mathrm{l}$ ) of human mummy of 21st Dynasty, ca $1065 \mathrm{BC}$, from Deir-el-Bahri $\left(25^{\circ} 40^{\prime} \mathrm{N}, 32^{\circ} 40^{\prime} \mathrm{E}\right)$. Coll 1906 by E Naville and subm 1981 by D P Dawson and N Thomas, City of Bristol Mus, as part of project for dissection of mummy ( $c f$ Manchester Mummy Project, David, 1979; BM-1602, -1839, above). Comment (RB): provisional calibrated date of ca $1145 \pm 150$ BC (Clark, 1975) agrees with expected hist date when allowance made for probable age of wood.

\section{Arcy series}

\section{F. France}

Collagen from partially burned animal bone from cave site at Grotte du Renne, Arcy, near Auxerre, Yonne $\left(47^{\circ} 40^{\prime} \mathrm{N}, 3^{\circ} 50^{\prime} \mathrm{E}\right)$ assoc with Middle Palaeolithic industries (Leroi-Gourhan and Leroi-Gourhan, 1964). Coll 1960-1965 and subm by F Hours, Univ Lyons. Comment supplied by $G$ de G Sieveking, Dept Prehist and Romano-British Antiquities, British Mus.

\section{BM-1817. Arcy}

Sample VII.

BM-1818. Arcy

Sample XIII.

\section{BM-1819. Arcy}

\section{Sample VIIIc.}

General Comment (GdeGS): cf GrN-1717: 30,800 \pm 250 and -1742: 33,860 $\pm 250, \mathrm{R}, 1963, \mathrm{v} 5, \mathrm{p} 166$. These results differ from our present ideas of chronol of site. It seems likely that samples were either wrongly labelled or misassoc.

\section{Servia series}

\section{G. Greece}

Collagen from bone samples (id by J Watson) from Neolithic and Bronze age levels at Servia, W Macedonia $\left(40^{\circ} 10^{\prime} \mathrm{N}, 22^{\circ} 0^{\prime} \mathrm{E}\right)$. Coll 1972 1973 and subm by Cressida Ridley, British School Archaeol at Athens (Heurtley, 1939; Ridley and Wardle, 1979).

\section{BM-1885. Servia}

Unit 3644. Bos from Early Neolithic level.

BM-1886. Servia

$$
\begin{array}{r}
6360 \pm 190 \\
\delta^{19} C=-23.2 \% \text { o }
\end{array}
$$

Unit 1228. Bos from Early Bronze Age I (Tatar) level in middle fill of $\mathrm{N}$ ditch. 
BM-1887. Servia

Unit 2118. Cervus from Late Neolithic (Larissa) yard floors.

\section{BM-1888. Servia}

$3560 \pm 70$

Units 3408 and 3409 . Bos and Ceruus from Farly Bronze Age II level in Pit 1.

General Comment (RB \& JW): samples dated to resolve apparent stratigraphic anomalies of previous series (see BM-XI, R, 1979, v 21, p 348-349). BM-1885 comprised two articulating bones and should date unit more reliably than single unassoc bone; BM-1886 was single scapula, probably also in situ. BM-1885 is, however, much later than expected for Greek Early Neolithic; BM-1887 is within expected range. BM-1886, -1888 are later than expected, but agreement of BM-1888 with previous date from same pit (BM-1108: $3694 \pm 98, \mathrm{R}, 1979$, v 21, p 349) suggests Early Bronze Age II, later than previously thought.

\section{Tell Abada series}

\section{H. Iraq}

Charcoal from levels in 'Ubaid Tell of Abada, near Al Miqdādiyah, E Iraq ( $\left.34^{\circ} 10^{\prime} \mathrm{N}, 45^{\circ} 20^{\prime} \mathrm{E}\right)$. Coll 1979 by $\mathrm{S} \mathrm{A}$ Jasim and subm by Joan Oates, Girton Coll, Univ Cambridge (Aboud, 1979).

BM-1822. Tell Abada $\quad \delta^{13} \mathrm{C}=-25.9 \%$

$31,000 \pm 1250$ Level 1.

Charcoal in clay matrix. Sample Abd 612, from fill of small room in

\section{BM-1823. Tell Abada}

Sample Abd 726 from fill between Levels II and III.

$$
\begin{array}{r}
\mathbf{5 7 7 0} \pm \mathbf{4 5} \\
\delta^{13} C=-26.9 \%
\end{array}
$$

General Comment (JO): BM-1822 invalidated by misassoc (expected date ca $6500 \mathrm{bp}$ ), possibly by contamination from "industrial"/kiln area in Level III. BM-1823 is later than expected; site is significantly earlier than Tell Madhhur, BM-1458: $5574 \pm$ 55, (BM XIV, R, 1982, v 24, p 248).

\section{BM-1856. Nimrud}

$$
\begin{array}{r}
2300 \pm \mathbf{5 0} \\
\delta^{13} C=-23.3 \%
\end{array}
$$

Charcoal (ref BP23) from Burnt Palace of Nimrud, Mesopotamia $\left(36^{\circ} 10^{\prime} \mathrm{N}, 43^{\circ} 20^{\prime} \mathrm{E}\right)$ from box containing ingots of cuprite glass deposited in British Mus Res Lab. Coll ca 1952 by M E L Mallowan and subm 1981 by Mavis Bimson, British Mus Res Lab. Comment (MB \& $\mathrm{RB})$ : material was originally dated from archaeol evidence to 7 th century BC, but later assigned to 2nd-3rd century BC (Arkell, 1957); correction of result for natural ${ }^{14} \mathrm{C}$ variations and allowance of $50-75$ yr for age of wood, yields date са $350 \mathrm{BC}$ and supports later dating if assoc of sample with glass is accepted. 


\section{Jericho series}

\section{Jordan}

Charcoal from Jericho (31 $\left.50^{\prime} \mathrm{N}, 35^{\circ} 30^{\prime} \mathrm{E}\right)$. Coll 1959 by Kathleen Kenyon and subm by $\mathrm{T}$ Holland, British School Archaeol, Jerusalem. BM-1787, -1789 from PPNA levels; BM-1769 to -1779 , -1793 from PPNB levels; BM-1778 to -1784, -1791 from Bronze age levels; BM-1774, -1775 from Proto-Urban levels; BM-1790 from Iron age destruction level.

\section{BM-1769. Jericho}

$8700 \pm 110$

Sample, ref SA.1010, JpM 7.11D, from Sq M, Phase XI.1via, PPNB.

\section{BM-1770. Jericho}

$8680 \pm 70$

Sample, ref SA.968, JpM 6.11a, from Sq M, Phase XI.1xa, PPNB.

\section{BM-1771. Jericho}

$8660 \pm 260$

Sample, ref SA.823, JpM 6.8, from Sq M, Phase XIII.1xxa, PPNB.

\section{BM-1772. Jericho}

$8810 \pm 100$ PPNB.

Sample, ref SA.751, JpM 6.6b, from Sq M, Phase XIII.lxxiv-XIV.1xxv,

\section{BM-1773. Jericho}

$\mathbf{8 7 3 0} \pm \mathbf{8 0}$

Sample, ref SA.680, JpM 6.6, from Sq M, phase XIV.lxxvi, PPNB.

\section{BM-1774. Jericho}

$\mathbf{4 3 8 0} \pm \mathbf{5 0}$

Sample, ref S.25, from Tomb A 94, Proto-Urban.

\section{BM-1775. Jericho}

Sample, ref S.21, from Tomb A 94, Proto-Urban.

$$
\begin{array}{r}
\mathbf{4 4 8 0} \pm \mathbf{5 0} \\
\delta^{13} C=-26.1 \% \circ
\end{array}
$$

\section{BM-1778. Jericho}

$$
4080 \pm 70
$$

Sample, ref SA.613, JpN 6.24, from Site N, Phase XVI.1xii-lxiii, Bronze age.

BM-1779. Jericho

$$
4160 \pm 80
$$

Sample, ref SA.724, JpN 5.53, from Site N, Phase XVI.1xii-1xiii, Bronze age.

BM-1780. Jericho

$3890 \simeq 60$

Sample, ref SA.699, JpN 5.30, from Site N, Phase XVII.lxviiia, Bronze age. 
BM-1781. Jericho

$4120 \pm 40$

$\delta^{13} \mathrm{C}=-25.6 \%$ Bronze age.

BM-1782. Jericho

$3560 \pm 40$

Sample, ref CS.112, JpN 2.11, from Site N, Phase XX.1xxxa, Bronze age.

BM-1783. Jericho

$3940 \pm 80$

Sample, ref SA.966, JpO 103.34, from Site O, Phase XVIII.1viii, Bronze age.

BM-1784. Jericho

$3620 \pm 40$

Sample, ref SA.774, JpO 110.9, from Site O, Phase XXI.lxviiiXXII.1xix(a), Bronze age.

BM-1787. Jericho

$9280 \pm 100$

Sample, ref SA.1090, JpF 201.25b from Sq F, Phase VIII A.xv, PPNA.

BM-1789. Jericho

$9200 \pm 70$

Sample ref SA 822 JpF $1119 \mathrm{~b}$, from Sq F, Phase IX

BM-1790. Jericho

$3080 \pm 40$

Sample, no ref no., JpH 155.2, from Sq H, Phase XII.li, Bronze age.

BM-1791. Jericho

$$
2040 \pm 40
$$

Sample, ref S2, JpC 5.1jb, from Site C, Phase XLVII-1xxii-1xxiii(1), Iron age destruction.

\section{BM-1793. Jericho}

$8660 \pm 130$

Sample, ref SA.755, JpD 103A.15, from Sq D, Phase XIV.xxxvii, PPNB.

General Comment (RB): for check-list of all BM-, GL-, Gro-, GrN-, and P- dates for Jericho (55 dates) see Burleigh, 1981; full assessment of these and 19 supplementary dates in this list will appear in Jericho excavation mon, $\mathrm{v} 5$ (Burleigh, ms in preparation).
J. Norway
BM-1880. Grasvatn
$6460 \pm 60$
$\delta^{13} C=-25.6 \%$
Clastic wood (Pinus) of 20 rings, from beneath peat just above SE shore of lake at Grasvatn, Nordland $\left(66^{\circ} 0^{\prime} \mathrm{N}, 14^{\circ} 30^{\prime} \mathrm{E}\right)$, assoc with early phase of occupation by hunter-fishers and higher tree line than 
present. Coll 1980 and subm by P Worsley, Dept Geog, Univ Reading. Comment $(\mathrm{PW})$ : result confirms that sample is probably standard drift $\log$ deposited on beach of lake soon after death of tree; allows calibration of uplift curve (Worsley, 1970; 1975). Sub-fossil tree trunks assoc with retreat of Lapland pine forest are rarely preserved in peat bogs (Eronen, 1979); Grasvatn is one of these rare sites. Cf Birm-117: $6990 \pm 120$ (R, 1970 , v 12, p 398), date for charcoal from soil underlying peat bed.

\section{K. Pakistan}

\section{Tarakai Kala Dherai series}

Charcoal samples from Kot Dijian period floors at Tarakai Kala Dherai, small mound on Tochi R, SW of Bannu City, Northwest Frontier Prov $\left(33^{\circ} 0^{\prime} \mathrm{N}, 70^{\circ} 30^{\prime} \mathrm{E}\right)$, assoc with typical Kot Dijian assemblage. All samples from Trench IA except BM-1693. Coll 1979 and subm by K D Thomas, Inst Archaeol, Univ London and Cambridge Archaeol Mission to Pakistan.
BM-1690. Tarakai Kala Dherai
$3640 \pm 80$
Sample TRQ I A E7, from under degraded mud-brick.

$$
\delta^{13} C=-24.1 \%
$$

BM-1691. Tarakai Kala Dherai

$3510 \pm 60$

Sample TRQ I A E11.

$$
\delta^{13} C=-23.9 \%
$$

BM-1692. Tarakai Kala Dherai

$3680 \pm 50$

Sample TRQ I A E67.

BM-1693. Tarakai Kala Dherai

$3810 \pm 60$

$\delta^{13} C=-24.3 \%$

Sample TRQ I BC E114, from occupation level in Tr IB to E of mud wall.

\section{BM-1694. Tarakai Kala Dherai}

Sample TRQ I A E130, from deep sounding.

\section{BM-1695. Tarakai Kala Dherai}

Sample TRQ I A E135, from deep sounding.

$$
\begin{array}{r}
\mathbf{3 7 7 0} \pm \mathbf{9 0} \\
\delta^{13} C=-23.7 \% \text { o }
\end{array}
$$

$$
4060 \pm 120
$$$$
\delta^{13} \mathrm{C}=-24.0 \%
$$

General Comment (KT): dates are internally consistent and support theory that occupation of site was short-lived but continuous. Dates for other sites in Pakistan (Rehman Dheri, PRL-673 to -676, -679; Durrani, 1981; Kot Diji, P-179, -195, -196; Khan, 1981) suggest that Kot Dijian. occupation ended ca $2500 \mathrm{BC}$. These results suggest later survival of Kot Dijian traits in $\mathrm{N}$ of Pakistan where there is no evidence for Indus Valley civilization. 


\section{Spain}

\section{BM-1677. Ca Na Costa, Formentera, Baleares}

$$
\begin{array}{r}
\mathbf{3 2 7 0} \pm \mathbf{8 0} \\
\delta^{13} C=-18.9 \%
\end{array}
$$

Collagen from human bone fragments from Quad 4 of chambered tomb at Ca Na Costa, E of Es Pujoles $\left(38^{\circ} 40^{\prime} \mathrm{N}, 1^{\circ} 30^{\prime} \mathrm{E}\right)$. Coll 1975 and subm by Celia Topp, Archaeol Mus, Ibiza (Topp, Fernandez, and Flantalamor, 1976). Comment (CT): agrees with date for megalith of 19:0-1600 BC based on pottery analogies.

\section{BM-1696. Son Oms, Mallorca, Baleares}

$$
2290 \pm 40
$$
ment site at Son Oms, Palma $\left(39^{\circ} 30^{\prime} \mathrm{N}, 2^{\circ} 30^{\prime} \mathrm{E}\right)$. Coll 1980 by G Rossello-Bordoy, Dir Mus Mallorca, Palma and subm by W H Waldren, Donald Baden-Powell Quaternary Res Centre, Pitt Rivers Mus, Univ Oxford and Dir, Deya Archaeol Mus and Res Centre, Deya de Mallorca (Waldren, 1981). Comment (WHW): lst time carbonized grain dated in Mallorca. Other dates for this site, Y-2666: $2490 \pm 40$, QL-20: $2920 \pm 60$, both unpub.

\section{BM-1697. Taula de Torralba d'en Salort, $\quad 2860 \pm 45$ Menorca, Baleares $\quad \delta^{13} C=-22.2 \%$ o}

Sample of carbonized grain from central structure at Taula de Torralba d'en Salort $\left(40^{\circ} 0^{\prime} \mathrm{N}, 4^{\circ} 0^{\prime} \mathrm{E}\right)$. Coll 1980 and subm by $\mathrm{W} \mathbf{H}$ Waldren. Comment (WHW): 1st time grain dated from Menorca; result correlates with date for similar grain sample of $3030 \pm 70$ (QL-unnumbered, unpub). For other dates from site, see Waldren (1981).

\section{Ferrandell Oleza series, Mallorca, Baleares}

Samples from Beaker settlement site at Ferrandell Oleza, Valldemosa $\left(39^{\circ} 40^{\prime} \mathrm{N}, 2^{\circ} 30^{\prime} \mathrm{E}\right)$ assoc with Beaker and indigenous Pretalayotic pottery and flint implements. Coll 1980 and subm by W H Waldren.

\section{BM-1698. Ferrandell Oleza}

$3090 \pm 70$

Collagen from bone sample, from Circle 1.

$$
\delta^{13} C=-22.0 \%
$$

BM-1842. Ferrandell Oleza

$$
2430 \pm 230
$$

$\delta^{13} C=-21.7 \%$

Collagen from bone sample, from Talayot 1, Ferrandell Oleza Younger Settlement.

\section{BM-1843. Ferrandell Oleza}

$$
\begin{array}{r}
3950 \pm \mathbf{6 0} \\
\delta^{13} C=-23.9 \% \text { o }
\end{array}
$$

Charcoal from $\mathrm{E}$ wall of central zone, of Beaker settlement directly assoc with Beaker ware. Comment (WHW): 1st time Beaker pottery and ${ }^{14} \mathrm{C}$ date of $2000 \mathrm{bc}$ have been recorded from open-air settlement in Baleares; cf such S French sites as Lébous, La Couronne, and La Balance (Languedoc and Provence). For other dates from this site, see Waldren (1981). 


\section{BM-1739. La Riera}

$\mathbf{2 0 , 8 8 0} \pm \mathbf{4 1 0}$

$\delta^{13} \mathrm{C}=-20.7 \%$

Bone fragments from Level 26 (now Level 1) at La Riera Cave, Posada de Llanes, Asturias $\left(43^{\circ} 25^{\prime} \mathrm{N}, 5^{\circ} 50^{\prime} \mathrm{W}\right)$. Sample from basal level at site, assoc with possible Aurignacian lithic industry (Straus and Clark, 1978a, b; 1979; Straus et al, 1980). Coll 1978 and subm by L G Straus, Univ New Mexico. Comment (LGS): cf Ly-1783: 20,360 \pm 450, unpub and BM-1404: 10,634 \pm 121 ; BM XIV (R, 1982, v 24, p 251). Lithic industry must be either early Solutrean without points or late form of some other industry.

\section{Cueva de los Azules series}

Collagen from bone samples from Azilian levels at Cueva de los Azules, Cangas de Onis, Asturias $\left(43^{\circ} 20^{\prime} \mathrm{N}, 5^{\circ} 0^{\prime} \mathrm{W}\right)$. Coll 1980 and subm by J Fernandez-Tresguerres, Oviedo. Comment supplied by $\mathrm{G}$ de G Sieveking, Dept Prehist and Romano-British Antiquities, British Mus.

\section{BM-1875. Cueva de los Azules \\ From Sec DIV. \\ BM-1876. Cueva de los Azules From Sec DIV.}

$10,330 \pm 190$

\section{BM-1877. Cueva de los Azules}

From Sec DIV.

\section{BM-1878. Cueva de los Azules}

From Sec F III.

$\delta^{13} C=-21.7 \%$

\section{BM-1879. Cueva de los Azules}

From Sec C VIII.

General Comment (GdeGS): determinations were carried out on different levels within shell-midden, assoc with Azilian industry. These shell deposits accumulate quickly and results suggest that different habitation levels represent successive stages of accumulation over short period. Number of other dates for Azilian industry fall between 10,000-12,000 bp, in same interval as those of latest Magdalenian culture (incl prelim date 10,550 for this site, details not available). Present series of dates overlap, but as they are stratigraphically successive, they provide useful confirmatory evidence of existence of Azilian culture in this period.

\section{Hornos de la Peña series}

Collagen from bone samples from Palaeolithic cave site containing parietal art (Breuil and Obermaier, 1912) at Hornos de la Peña, Santander $\left(43^{\circ} 15^{\prime} \mathrm{N}, 3^{\circ} 40^{\prime} \mathrm{W}\right)$. Coll 1912 and subm 1980 by V Cabrera and F Bernaldo de Quiros, Dept Prehist, Univ Alcalca de Henares, Madrid. Comment supplied by $\mathbf{G}$ de $\mathbf{G}$ Sieveking. 


\section{BM-1881. Hornos de la Peña}

Sample 1.

BM-1882. Hornos de la Peña

Sample 2.

\section{BM-1883. Hornos de la Peña}

Sample 3.

\section{BM-1884. Hornos de la Peña}

Sample 4.

General Comment (GdeGS): dates appear to be in correct stratigraphic order and show that latest inhabitants were either of Solutrean or at most early Magdalenian culture; assoc material needs re-examination.

\section{Tell Abu Hureyra series}

$$
\text { M. Syria }
$$

Charcoal from Tell Abu Hureyra, near village of Abu Hureyra, N Syria $\left(35^{\circ} 50^{\prime} \mathrm{N}, 38^{\circ} 20^{\prime} \mathrm{E}\right)$. Coll $1972-1973$ and subm by A M T Moore, Donald Baden-Powell Quaternary Res Centre, Pitt Rivers Mus, Univ Oxford (Moore, 1975).

\section{BM-1718. Tell Abu Hureyra}

$11,160 \pm 110$

in base of Mesolithic sequence.

BM-1719. Tell Abu Hureyra

$$
9120 \pm 50
$$$$
\delta^{13} C=-27.0 \%
$$

Sample E 254197 from floor surface in Mesolithic settlement, near top of Mesolithic sequence.

BM-1720. Tell Abu Hureyra

$21,940 \pm 180$

Sample D 6857 from occupation level assoc with mud-brick house.

\section{BM-1721. Tell Abu Hureyra}

$8410 \pm 60$

Sample D 4247 from level assoc with bldg in early ac lithic phase.

BM-1722. Tell Abu Hureyra

$$
8610 \pm 50
$$

Sample B 136102 from occupation deposit assoc with mud-brick house in early aceramic Neolithic phase.

\section{BM-1723. Tell Abu Hureyra}

$$
\mathbf{1 0 , 7 0 0} \pm \mathbf{5 0 0}
$$$$
\delta^{13} C=-25.7 \%
$$

Samples E 229 and E 2211 from level assoc with mud-brick house just below ceramic Neolithic layers. 


\section{BM-1724. Tell Abu Hureyra}

$\mathbf{7 9 0 0} \pm \mathbf{5 0}$

Samples E 5589 and E 5592 from level assoc with mud-brick houses in late aceramic Neolithic.

General Comment (AMTM): cf BM-1120: $8666 \pm 66,-1121: 10,792 \pm 82$; $-1122: 9374 \pm 72,-1423: 8676 \pm 72,-1424: 8190 \pm 77,-1425: 8393 \pm 72$, BM XIV (R, 1982, v 24, p 252-253).

\section{Tell Brak series}

Samples from occupation site at Tell Brak, near El Haseke, NE Syria $\left(36^{\circ} 40^{\prime} \mathrm{N}, 41^{\circ} 0^{\prime} \mathrm{E}\right)$. BM-1758, -1759 from clay oven, probably Late Uruk/Jamdat Nasr, BM-1760, -1763 to -1765 from burned house probably destroyed at end of Agada occupation (Mallowan, 1947; Oates, 1977). Coll 1978 and subm by D Oates, Inst Archaeol, Univ London.

\section{BM-1758. Tell Brak}

Charcoal, Sample CHD 67.

\section{BM-1759. Tell Brak}

Charcoal, Sample CHD 64.

\section{BM-1760. Tell Brak}

Charcoal, Sample ER/2-27 (28) (BM no. 5).

\section{BM-1761. Tell Brak} pottery.

$$
\begin{array}{r}
\mathbf{3 6 8 0} \pm \mathbf{5 0} \\
\delta^{13} C=-24.3 \%
\end{array}
$$

$$
3710 \pm 60
$$$$
\delta^{1 s} C=-25.7 \% \text { o }
$$

$$
4060 \pm 50
$$$$
\delta^{13} C=-26.3 \%
$$

$4040 \pm 70$ $\delta^{13} C=-25.4 \%$ o

\section{BM-1763. Tell Brak}

Burned grain, Sample ER/2-27 (BM no. 1).

\section{BM-1764. Tell Brak}

Burned grain, Sample ER/2-27/4 (BM no. 4).

\section{BM-1765. Tell Brak}

Burned grain, Sample ER/2-28 (No. 4) (BM no. 3).

General Comment (DO): there are only two previous stratified Uruk dates, no Agada dates and no agreed detailed chronol for period as a whole, but present dates (BM-1758 to -1761, -1763 to -1765), even when corrected for natural ${ }^{14} \mathrm{C}$ variations, do not conform with known broad hist dating; further samples are being measured in attempt to resolve this discrepancy and dates will be pub with full comment on both series in BM-XVI (in press). 


\section{Can Hasan series}

$$
\text { N. Turkey }
$$

Charcoal from Trench 49L in aceramic levels in Neolithic Mound III at Can Hasan, Anatolia (37 $\left.30^{\prime} \mathrm{N}, 33^{\circ} 30^{\prime} \mathrm{E}\right)$. Coll 1969 and subm by $\mathrm{D} H$ French, British Inst Archaeol at Ankara.

BM-1655. Can Hasan

Sample $6 \mathrm{~F}$.

BM-1656. Can Hasan

Sample $17 \mathrm{~F}$.

BM-1657. Can Hasan

Sample 28 F 3.

BM-1658. Can Hasan

Sample $29 \mathrm{~F}$.

BM-1660. Can Hasan

Sample 63 F.

BM-1662. Can Hasan

Sample 148 F.

BM-1663. Can Masan

Sample 149 F.

BM-1664. Can Hasan

Sample 156 F.

BM-1665. Can Hasan

Sample 158 F.

\section{BM-1666. Can Hasan}

Sample 162 F.

\section{BM-1667. Can Hasan}

Sample 162 F 2.

$$
\begin{array}{r}
\mathbf{7 6 6 0} \pm \mathbf{7 0} \\
\delta^{13} C=-23.4 \% 0 \\
\mathbf{7 7 7 0} \pm \mathbf{1 0 0} \\
\delta^{13} C=-23.4 \% 0
\end{array}
$$

$$
\begin{array}{r}
7760 \pm 90 \\
\delta^{13} C=-24.6 \%
\end{array}
$$

$$
\begin{array}{r}
\mathbf{7 6 0} \pm \mathbf{9 0} \\
\delta^{13} C=-23.8 \% \\
7990 \pm \mathbf{1 1 0} \\
\delta^{13} C=-23.1 \%
\end{array}
$$

$$
\begin{array}{r}
8050 \pm 60 \\
\delta^{13} C=-23.9 \%
\end{array}
$$

$$
7910 \pm 190
$$

$\delta^{13} C=-23.1 \%$ o

$$
\begin{array}{r}
8120 \pm 110 \\
\delta^{13} C=-24.9 \% \text { o } \\
7990 \pm 130 \\
\delta^{13} C=-23.6 \% 0
\end{array}
$$

$$
8160 \pm 110
$$$$
\delta^{13} C=-23.8 \% \text { o }
$$

$$
8360 \pm 60
$$$$
\delta^{13} C=-23.8 \% \text { 。 }
$$

General Comment (DHF): samples are listed in stratigraphic order as excavated; for account of excavation and description of site, see French et al (1972) and Mellaart (1975, p 96-98, 285). Cf dates from Chalcolithic mound, Can Hasan I: BM-151: $6880 \pm 150,-153: 7190 \pm 150$, R, 1968, v 10, p 6, and other dates for Mound III: HU-9: $7874 \pm 70,-10: 7796 \pm$ 140, -11: $8584 \pm 65,-12: 8543 \pm 66($ Ergin, 1979). 


\section{Doroslovo series}

$$
\text { O. Yugoslavia }
$$

Charcoal and human bone from Iron-age urnfield at Djepfeld, Doroslovo, near Sombor, N Yugoslavia $\left(45^{\circ} 40^{\prime} \mathrm{N}, 19^{\circ} 15^{\prime} \mathrm{E}\right)$. Coll 1979 and subm by $S$ Živanović, Dept Anatomy, St Bartholomew's Hosp Medical Coll, London.

BM-1830. Doroslovo

$2370 \pm 40$

Charcoal from urn containing cremated human remains in Grave 146.

\section{BM-1831. Doroslovo}

$2010 \pm 70$

$C=-17.9 \%$ General Comment (RB): date for charcoal (BM-1830) agrees with expected date for assoc late Hallstatt grave goods (Trajković, 1977) and probably represents main period of use of urnfield, but date for human bone from Grave 18 (BM-1831) is definitely later, perhaps reflecting change in burial practice from cremation to inhumation despite apparent continuity in style of grave goods (Burleigh and Živanović, in press).

\section{GEOLOGIC SAMPLES}

\section{A. India}

Formation and weathering of late Pleistocene aeolian deposits

\section{Fossil coastal sediments series, Tirunelveli District}

Calcium carbonate (id as aragonite by thin sectioning and $x$-ray diffraction) from shells of land snails (Helix vittata) from $0.3 \mathrm{~m}$ layer incorporated in upper surface of overlying aeolianite (cemented dune sand), altered in places to calcrete and overlain by dune sand reddened in situ to max depth $10 \mathrm{~m}$, from Poochikadu and Thiruchendur, Tirunelveli Dist, Tamilnadu State, S India ( $\left.8^{\circ} 30^{\prime} \mathrm{N}, 78^{\circ} 0^{\prime} \mathrm{E}\right)$. Coll 1977 and subm by Rita A M Gardner, Dept Geog, Univ Oxford (now Dept Geog, King's Coll, London).

\section{BM-1670. Thiruchendur}

$21,000 \pm 400$

Sample ref $\mathrm{L} / \mathrm{NW} / 42$, in situ within upper layers of aeolianite, underlying modern dune deposit.

\section{BM-1671. Poochikadu}

$\mathbf{2 4 , 4 5 0} \pm 750$ $\delta^{13} C=-7.6 \%$

Sample ref P1, in situ within upper layers of aeolianite, underlying red-weathered dune deposit.

General Comment (RAMG): results date late Pleistocene events in SE India: 2nd of 2 phases of aeolian activity in later part of last glacial correlates with peak of aridity ca 22,000-17,000 BP id elsewhere in tropics. Thus, geomorphol evidence and dates show Monsoonal SE India drier than at present from 25,000-20,000 BP. Dates provide max age and dura- 
tion ( $<20,000 \mathrm{yr}$ ) for rapid weathering (reddening) of aeolian deposits overlying land snail layer (reddening and assoc dates may suggest change to slightly wetter climate in early Holocene). Cf unpub dates for mollusks from raised littoral/lagoonal sediment (ca $6 \mathrm{~m}$ asl) underlying aeolianite (SRR-1482; 38,000 + 1200/-1100) and raised lagoonal sediments (2 to $3 \mathrm{~m}$ asl) to landward of deposits (SRR-1480: $4880 \pm 50$ ). For full discussion, see Gardner, 1981a, b; in press.

\section{REFERENCFS}

Aboud, S, 1979, Tell 'abada: Sumer, v 35, p 528-529.

Arkell, A J, 1957, Ancient red glass at University College, London: Jour Egyptian Archacol, v 43, p 110.

Bietak, M, 1979, Avaris and Pirmamesse: archaeological exploration in the eastern Nile delta (Mortimer Whceler archaeol lecture, 1979): British Acad Proc, v 65, p 225289, pls I-XXXVIIIb.

Breuil, H and Obermaier, H, 1912, Les premiers travaux de l'Institut de Paleontologie Humanine: L'Anthropologic, v 23, p 1-27.

Bryant, I D and Holyoak, D T, 1980, Devensian deposits at Brimpton, Berkshire: Quaternary Newsletter, no. 30, p 17.

Burleigh, R, 1981, Radiocarbon dates, in Kenyon, K M, (Holland, T A, ed), Excavations at Jericho, v 3, text, app C, p 501-504.

Burleigh, R and Kerney, M P, 1982, Some chronological implications of a forsil molluscan assemblage from a Neolithic site at Brook, Kent, England: Jour Archaeol Sci, v 9, p 29-38.

Burleigh, $\mathrm{R}$ and Zivanović, S, in press, A note on radiocarbon dating of human skeletal remains from the Iron age urnfield of Djepfeld, Doroslovo, near Sombor, Northern Yugoslavia.

Cheetham, G H, ms, 1975, Late Quaternary palaeohydrology with reference to the Kennet Valley: Unpub PhD thesis, Univ Reading.

Churchill, D M, 1962, The stratigraphy of the Mesolithic sites III and V at Thatcham, Berkshire, England: Prehist Soc Proc, v 28, p 362-370.

Clark, R M, 1975, A calibration curve for radiocarbon dates: Antiquity, v 49, p 251-266.

Clutton-Brock, $J$ and Burleigh, $R$, in press, Some archacological applications of the dating of animal bone by radiocarbon with particular reference to post-Pleistocene extinctions, in Internatl Symposium on C-14 and Archacol, 1st, Proc, Groningen, Netherlands, 24-28 Aug, 1981: PACT Jour.

David, A R, ed, 1979, Manchester Museum Mummy Project: Multidisciplinary research on ancient Egyptian mummified remains: Manchester, Manchester Mus.

Durrani, F A, 1981, Indus civilisation, evidence west of Indus, in Dani, A H, ed, Indus civilisation, new perspectives: Islamabad, Center Studies Civilization, Central Asia, p 133-138.

Ergin, M, 1979, The Hacettepe University Radiocarbon Laboratory and chronological prospection of the archaeological sites in Turkey: Chimica Acta 'Turcica, $v 7$, p 31-38.

Eronen, M, 1979, The retreat of pine forest in Finnish Lapland since the Holocene climatic optimum: a general discussion with radiocarbon evidence from subfossil pines: Fennia, v 157, p 93-114.

Faure, P, 1969, Sur trois sortes de sanctuaries crétois: Correspondence Hellénique Bull, v 93, p $174-213$.

French, D H, Hillman, G C, Payne, S and Payne, R J, 1972, Excavations at Can Hasan III 1969-1970, in Higgs, E S, ed, Papers in economic prehistory: Cambridge, Cambridge Univ Press, p 180-190.

Gardner, R A M, ms, 1981a, Geomorphology and environmental change in S India and Sri Lanka: Unpub DPhil thesis, Univ Oxford.

$1981 \mathrm{~b}$, Reddening of dune sands_evidence from southeast India: Earth Surface Processes and Landforms, v 6, p 459-468.

in press, Reddening of tropical dune sands: Geol Soc (London), spec pub.

Harding, A F, 1981, Excavations in the prehistoric ritual complex near Milfield, Northumberland: Prehist Soc Proc, v 47, p 87-135, pls 3-5.

Harrison, D L, Clutton-Brock, J, and Burleigh, R, 1981, Remains of mammals from the Darent river gravels at Sevenoaks Reserve, Kent: Archaeol Cantiana, v 97, p 27-52, pls I-V. 
Heurtley, W A, 1939, Prehistoric Macedonia: an archaeological reconnaissance of Greek Macedonia (W of the Sturna) in the Neolithic, Bronze and Early Iron ages: Cambridge, Cambridge Univ Press.

Holyoak, D, 1978, Notes on early Flandrian deposits in the Kennet valley (Berkshire): Quaternary Newsletter, no. 24, p 7-8.

valley ms, 1980, Late Pleistocene sediments and biostratigraphy of the Kennet valley, England: Unpub PhD thesis, Univ Reading.

Jackson, J W and Kennard, A S, 1909, On the former occurrence of Unio (Margaritana) Margaritifer Linné in the River Thames: Jour Conchol (London), v 12, p 321-322.

Keen, D H, 1981, The Holocene deposits of the Channel Islands: IGS Rpt 81/10, London.

Kennard, A S, 1923, The Holocene non-marine Mollusca of England: Malacol Soc (London) Proc, v 15, p 241-259.

1943, Examples of Unio auricularius from the Holocene of Mortlake near London and L'Isle Adam (Seine-et-Oise), compared with recent specimens from the River Gironde, SW France: Geol Assoc (London) Proc, v 54, p 121.

Kennard, A S, Salisbury, A E, and Woodward, B B, 1925, Notes on the British postPliocene Unionidae with more especial regard to the means of identification of fossil fragments: Malacol Soc (London) Proc, v 16, p 267-285, pls 12-23.

Kerney, M P, 1958, On the occurrence of Margaritifera auricularia (Spengler) in the English Pleistocene: Jour Conchol (London), v 24, p 250.

1977, A proposed zonation scheme for Late-glacial and postglacial deposits using land Mollusca: Jour Archaeol Sci, v 4, p 387-390.

Kerney, M P, Preece, R C, and Turner, C, 1980, Molluscan and plant biostratigraphy of some late Devensian and Flandrian deposits in Kent: Royal Soc [London] Philos Trans B, v 291, p 1-43.

Khan, F A, 1981, Kot Diji culture, its greatness, in Dani, A H, ed, Indus civilisation, new perspectives: Islamabad, Center Studies Civilization, Central Asia, $\mathrm{p} \mathrm{15-24.}$

Kinnes, I A, 1982, Les Fouaillages and megalithic origins: Antiquity, v 56, p 24-30.

Leroi-Gourhan, A and Leroi-Gourhan, A, 1964, Chronologie des Grottes D'Arcy-sur-Cure (Yonne): Gallia Prehistoire, v 7, p 1-35.

Longin, R, ms, 1970, Extraction du collagene des os fossiles pour leur datation par la methode du carbone 14: Unpub doctoral thesis, Univ Lyons, France.

Mallowan, M E L, 1947, Excavations at Brak and Chagar Bazar: Iraq, v 9, p 1-258.

McGhee, R, 1980, Archaeology of the Eskimos: Popular Archaeol, v 2, pt 5, p 20-23.

McGhee, $\mathrm{R}$ and Tuck, J A, 1976, Un-dating the Canadian arctic: Am Archaeol Soc Mem, no. 31, p 6-14.

Mellaart, J, 1975, The Neolithic of the Near East: London, Thames and Hudson.

Moore, A M T, 1975, The excavation of Tell Abu Hureyra in Syria-a preliminary report: Prehist Soc Proc, v 41, p 50-77, pls VII-VIII.

Morzadec-Kerfourn, M-Th, 1974, Variations de la ligne de rivage Armoricaine au Quaternaire: Soc Géol et Min Bretagne Mém, no. 17.

Oates, D, 1977, The excavations at Tell Brak, 1976: Iraq, v 39, p 233-244, pls IV-X.

Preece, R C, Burleigh, R, Kerney, M P, and Jarzembowski, E A, in press, Radiocarbon age determinations of fossil Margaritifera auricularia (Spengler) from the River Thames in W London: Jour Archaeol Sci, in press.

Preece, R C, and Robinson, J E, in press, The molluscan and ostracod faunas from postglacial tufaceous deposits in Co Offaly: Royal Irish Acad Proc B, in press.

Ridley, C and Wardle, K A, 1979, Rescue excavations at Servia, 1971-1973-a preliminary report: British School Archaeol at Athens Ann, v 74, p 185-230, pls 26-28.

Sayed, Abdel Monem, A H, 1977, Discovery of the site of the 12th Dynasty port at Wãdi Gawāisis on the Red Sea shore: Rev Egyptol, v 29, p 140-178, pls 8-16. 1978, The recently discovered port on the Red Sea shore: Jour Egyptian Archaeol, v 64, p 69-71, pl XI.

1980, Observations on recent discoveries at Wādī Gawāsīs: Jour Egyptian Archaeol, v 66, p 154-157, pl XXI.

Schledermann, P, 1978, Preliminairy results of archaeological investigations in the Bache Peninsula region, Ellesmere Island, NWT: Arctic, v 31, p 459-474. 1981, Ellesmere Island-Eskimo and Viking finds in the High Arctic: Natl Geog, v 159, no. 5, p 575-601.

Scott, J E, and Hughes, E W, 1981, Chondroitin sulphate from fossilized antlers: Nature, v 291, p 580-581. 
Straus, L G and Clark, G A, 1978a, La Riera paleoecological project-preliminary report, 1977 excavations: Current Anthropol, v 19, p 455-456. v 5, 289-317.

1979, La Riera paleoecological project-preliminary report, 1978 excavations: Current Anthropol, v 20, p 235-236.

Straus, L G, Clark, G A, Altuna, J A and Ortea, J A, 1980, Ice-age subsistence in northern Spain: Sci Am, v 242, no. 6, p 142-152.

Todd, I A, 1979a, Vasilikos Valley Project, 1977-1978: an interim report: Dept Antiquities Cyprus rept 1979, p 13-68, pls I-IV.

$1979 \mathrm{~b}$, Vasilikos Valley project: third preliminary report, 1978: Jour Field Archaeol, v 6, p 265-300.

1981, Current research in the Vasilikos valley, in Reade, J, ed, Chalcolithic Cyprus and Western Asia (British Mus occ paper 26): London, British Mus, p 57-68. in press, Jour Field Archaeol.

Topp, C, Fernandez, J and Plantalamor, L, 1976, Ca Na Costa: a megalithic chamber tomb on Formentera, Balearic Islands: Univ London Inst Archaeol Bull, no. 13, p $139-175$.

Trajković, C, 1977, Halštatska Nekropola kod Doroslova: Sombor, Gradski Muzej.

Waldren, W, 1981, Radiocarbon determination in the Balearic Islands: Oxford, Donald Baden-Powell Res Centre.

Worsley, P, 1970, An investigation into Holocene stratigraphy and archaeology of south. east Grasvatn, in Prelim rept 1968, Okstindan Res Proj, Reading, p 6-24.

1975 , Some observations on lake ice-push features, Grasvatn, northern Scandinavia: Norsk geog tidsskr, v 20, p 11-19.

Wymer, J, 1962, Excavations at Maglemosian sites at Thatcham, Berkshire, England: Prehist Soc Proc, v 28, p 329-361. 